\title{
In situ measurements of cemented paste backfilling in an operating stope at Lanfranchi Mine
}

\author{
A Hasan The University of Western Australia, Australia \\ G Suazo The University of Western Australia, Australia \\ JP Doherty The University of Western Australia, Australia
}

AB Fourie The University of Western Australia, Australia

\begin{abstract}
This paper presents results from in-stope measurements of total stress and pore pressure during and after backfilling with cemented paste backfill (CPB). Measurements were taken at the Lanfranchi Nickel Mine, Western Australia, in collaboration with Panoramic Resources Ltd. The sensor installation procedure, which was developed to fit within a tight time production schedule, is described. Direct measurements of total stress, and pore pressure throughout filling and resting cycles at specific locations within the stope provide insight into the mechanical response of mine backfill during the filling and hydrating process, which is important for developing rational models to improve mine backfill management.
\end{abstract}

\section{$1 \quad$ Introduction}

Underground mined-out voids (stopes) result in stress concentrations in the adjacent intact rock which can produce instability and, in extreme cases, seismic activity (rockbursts). Backfilling is intended to improve the local and regional stability of the mine, to maximise ore production and the same time to reduce the surface storage of mine waste by placing it back underground.

CPB provides numerous advantages and fewer disadvantages over other backfill systems. As a result, mining industries in Australia and Canada have been favouring CPB since the mid-1990s (Henderson et al. 2005). Some advantages are: minimum excess water due to water retention properties of CPB, less cement binder usage, increased fill density, and shorter cycle times (Sveinson 1999; Henderson et al. 2005). These advantages translate into significant cost savings from reduced cement cost as well as increased productivity. For a $10,000 \mathrm{~m}^{3}$ stope (a medium sized stope, such as described in this paper), about $500 \mathrm{t}$ of cement binder is required, which translates to approximately AUD 125,000 based on the current cement binder price. Backfilling itself can account for $15-20 \%$ of the total mining costs (Yumlu 2001).

In order to optimise backfill management, a detailed understanding of the mechanical behaviour of CPB is necessary. There is still a shortage of in-stope measurements of CPB performance in the literature. Exceptions include measurements carried out at Chimo Mine, Quebec (Hassani et al. 1998), Doyon Gold Mine, Quebec (Belem et al. 2004), Bouchard-Hébert mine, Quebec (Oullet \& Hassani 2005), Alimak Mine, Ontario (Grabinsky et al. 2007), Kidd Mine, Ontario (Thompson et al. 2009), Çayeli Mine, Turkey (Thompson et al. 2012), Kanowna Belle mine, Western Australia (Helinski et al. 2011), and Raleigh mine, Western Australia (Hasan et al. 2013). This paper provides results from recent full-scale monitoring of CPB during and post-backfilling at Lanfranchi Nickel Mine, Western Australia.

\section{$2 \quad$ Methodology}

\subsection{Mine site}

In-stope monitoring was conducted at Lanfranchi Nickel Mine, Kambalda, Western Australia. The mine is operated by Panoramic Resources Ltd, and produces 10,000-12,000 t Ni and 1,000 t Cu per year (Panoramic 
Resources Ltd 2011). The instrumented stope is located at Deacon orebody (Figure 1), DCN 382A Panel 3. Sensors installation and subsequent monitoring took place between 3 and 19 August 2013.

\section{Lanfranchi Orebodies}

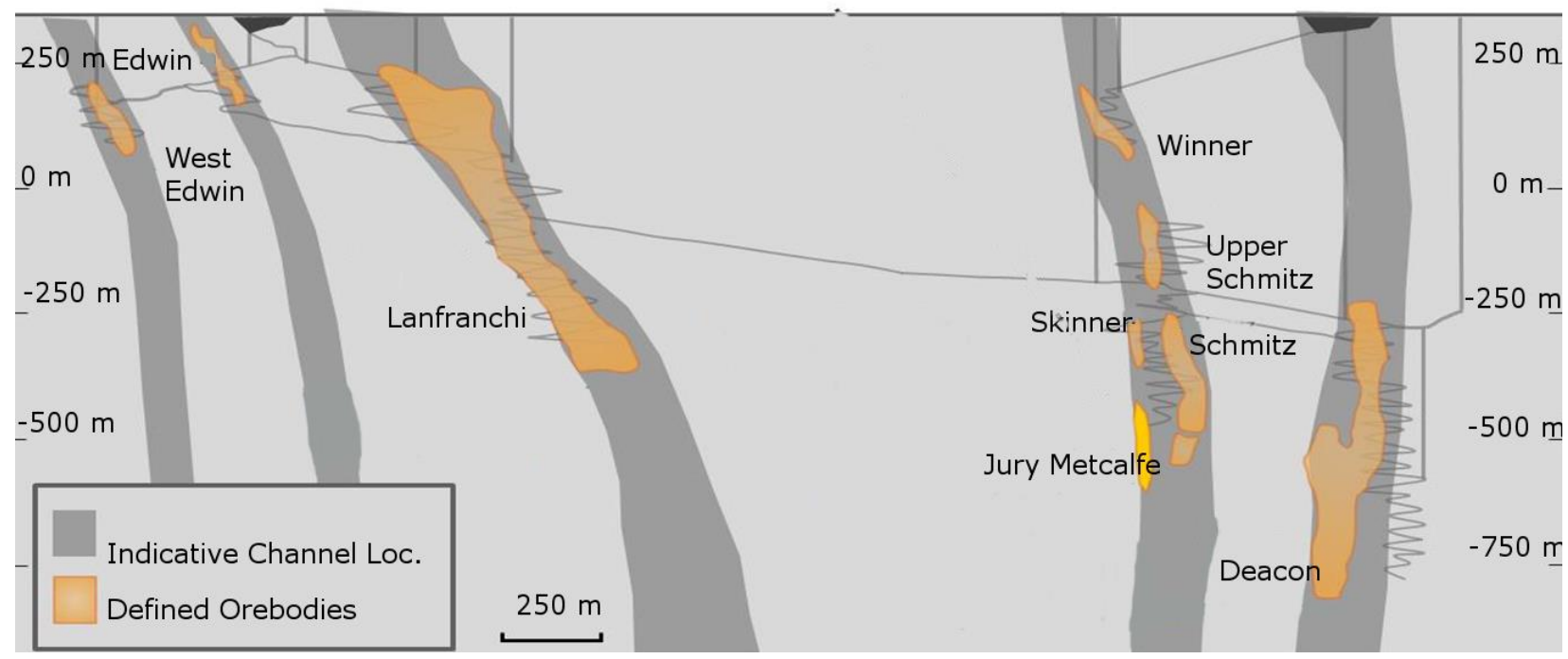

Figure 1 Orebodies at Lanfranchi Nickel Mine (Panoramic Resources Ltd 2011)

\section{$2.2 \quad$ Stope geometry}

Figure 2 shows stope images from a cavity monitoring survey (CMS). The stope consists of three access drives, i.e. upper, middle and lower drives. Curved 'Clunes' walls were used as barricades in the lower and middle drives, while a planar wall was used for the barricade in the upper drive. Walls were installed 4-5 $\mathrm{m}$ from the stope brow.

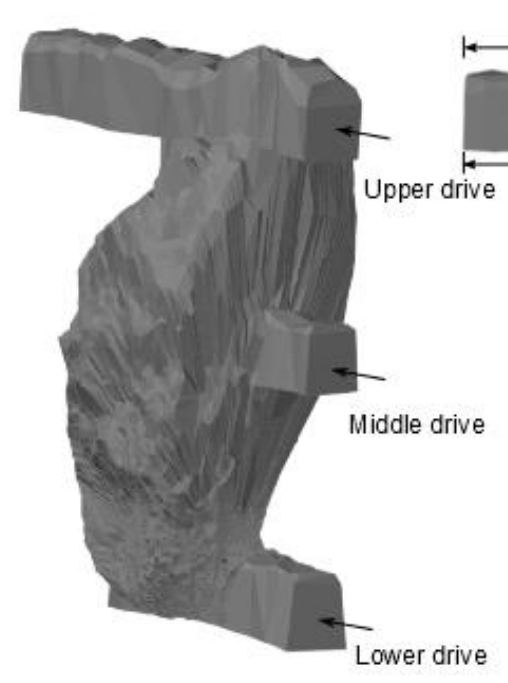

(a)

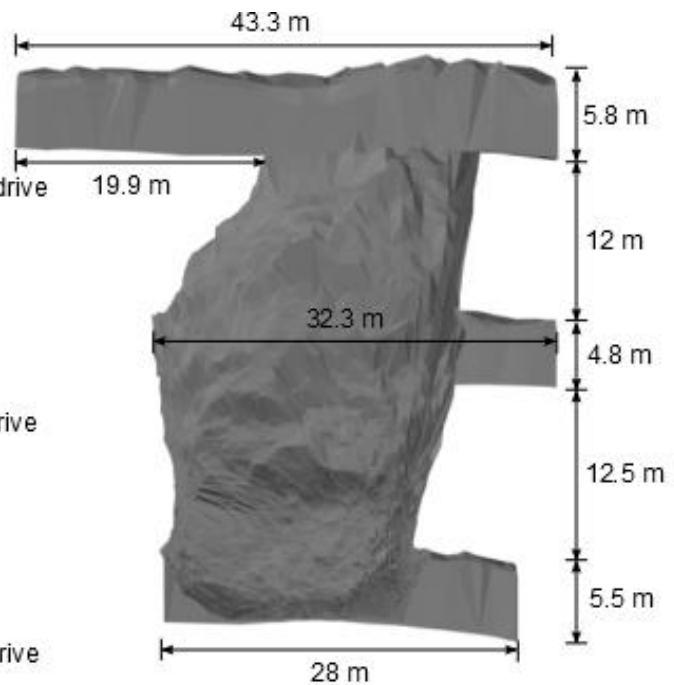

(b)

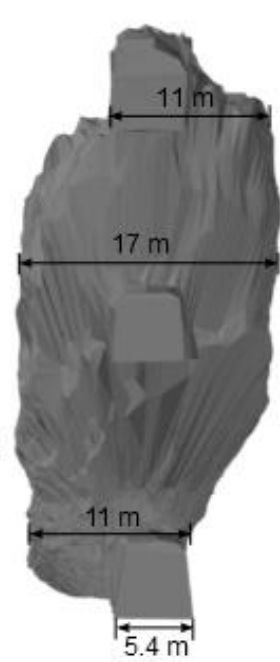

(c)

Figure 2 Stope geometry based on cavity monitoring survey

\subsection{Instruments}

Two types of sensors were installed prior to backfilling (Figure 3(a) and 3(b)). The first type was a total stress cell, Geokon (model number 4850NPST-1-700 kPa) NATM type, with a range of 0-700 kPa, a resolution of $\pm 0.025 \%$, and accuracy of $\pm 0.1 \%$. Total stress cells were fixed vertically and horizontally inside fabricated cages, which were hung from shackles (Figures 4 and 5). The cell is rectangular in shape, measures $10 \times 20 \mathrm{~cm}$, and is made from stiff plates to minimise under-registration (Fourie et al. 2007). The 
second type of sensor was a piezometer Geokon (model number 1200), with a range of 0-700 kPa, a resolution of $\pm 0.025 \%$ and an accuracy of $\pm 0.5 \%$, used to measure pore water pressure. Its tubular shape measures $19 \mathrm{~mm}$ in diameter and $136 \mathrm{~mm}$ in length, with a sintered stainless steel filter having a 20 micron opening. Both stress cells and piezometers have an internal vibrating wire transducer system and a thermistor. Data from the instrumentation was acquired using a battery powered DT80G data logger (Figure 3(c)).

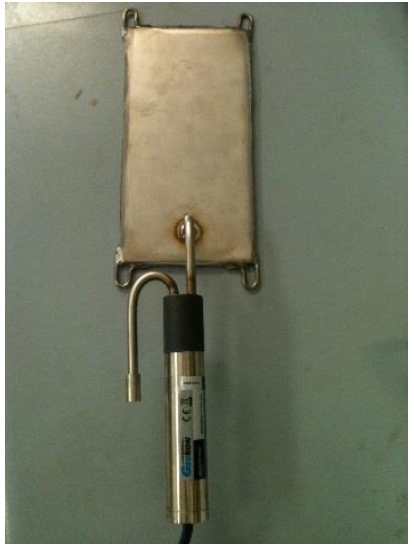

(a)

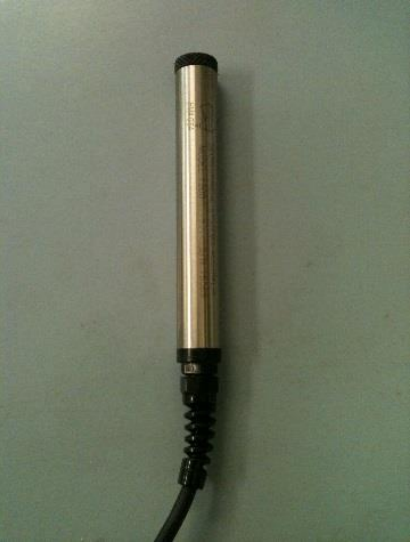

(b)

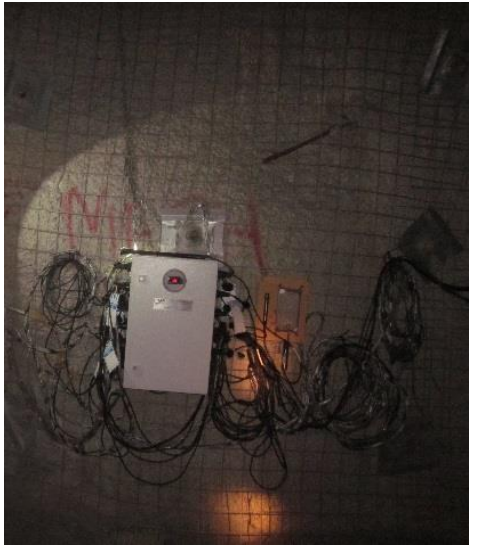

(c)

Figure 3 (a) NATM stress cell; (b) piezometer; (c) data logger

Figures 4(a) and (b) illustrate long and cross-sections of the stope, respectively. Sensors were positioned in three locations shown.

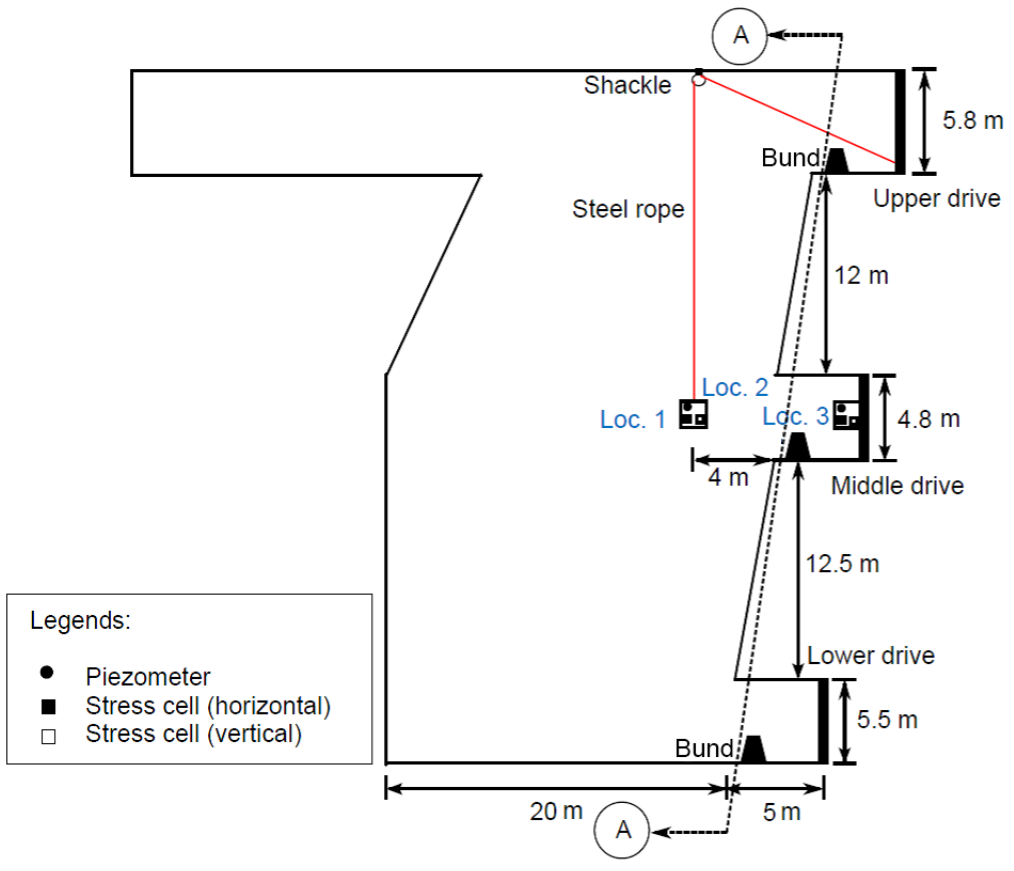

(a)

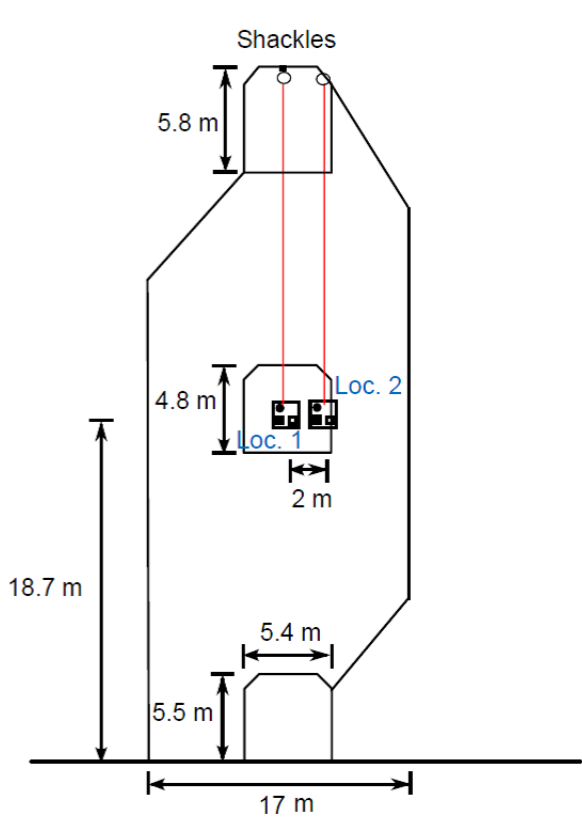

(b)

Figure 4 (a) stope long section; (b) stope cross-section A-A

\section{$2.4 \quad$ Installation}

The following procedure was used to install the sensors:

1. Cages, sensors and cabling were prepared on surface.

2. Shackles to hang sensors, with steel rope inserted, were installed prior to blasting the stope. 
3. The first steel rope, for cage location 1, was lowered from the upper drive through the shackle.

4. One end of the steel rope was connected to cage location 1 and pulled through the shackle from the upper drive until sensors were placed in the correct location. The other end of the steel rope was secured in the upper drive. Sensor cables were pulled separately (by a poly rope) to the stope, without passing through the shackle.

5. The second steel rope was lowered from the upper drive.

6. One end of the steel rope was connected to the cage at location 2 and pulled through the shackle from the upper drive until the sensors were positioned in the correct location. The other end of the steel rope was secured in the upper drive. Cables of the sensors were pulled separately (by a poly rope) to the upper drive, without passing through the shackle. Figure 5 shows cage locations 1 and 2 being installed.

7. Cage location 3 was hung with a rope at the centre of the middle barricade (inside). It was installed during the construction of the barricade frame. A plastic sheet was placed to protect the sensors against the shotcrete spray. Figure 6 shows cage location 3 hung and secured to the middle barricade. The cables were pulled, by a poly rope, to the upper drive.

8. Paste crews sprayed the shotcrete and allowed it to cure.

9. All sensor cables were connected to the data logger placed in the upper drive and data acquisition was commenced. The data was measured every 10 minutes. A fully charged battery ran for seven days before it required replacement.

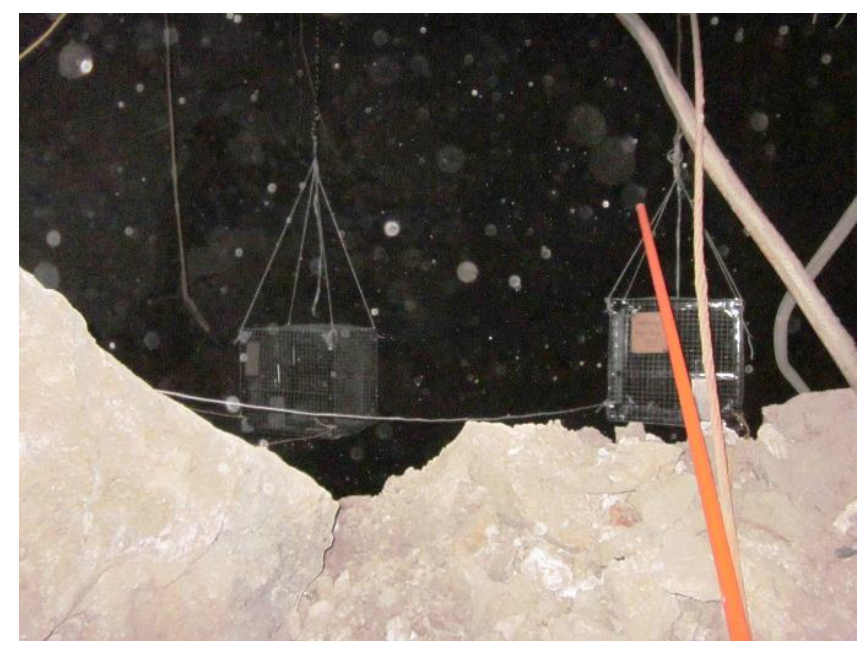

Figure 5 Cage location 1 and cage location 2 being installed

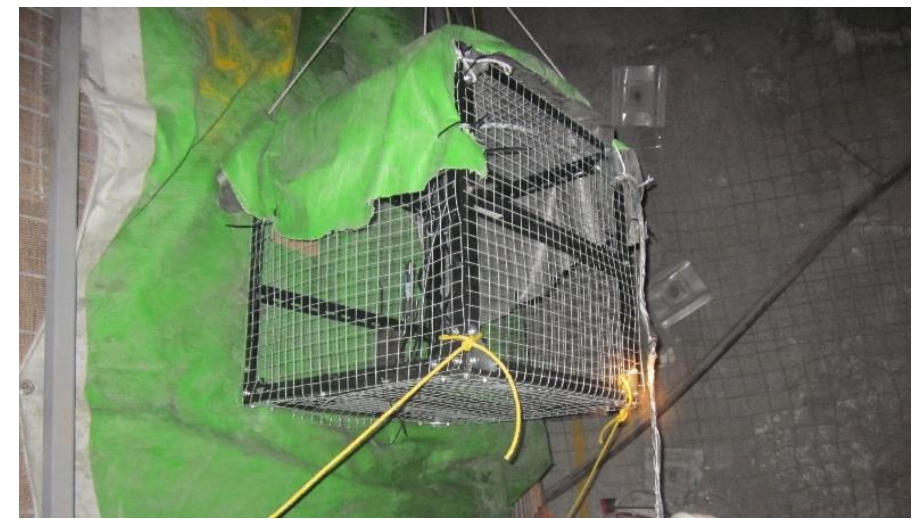

Figure 6 Cage containing sensors at location 3 (middle barricade) 


\section{$3 \quad$ Material properties}

\subsection{Tailings}

The CPB used in Lanfranchi stopes consists of tailings, a proprietary cement binder (Minecem), hypersaline groundwater and MMR01 (Meyco Minefill R01) chemical additive.

Tailings were recovered from a tailings storage facility (TSF) located near the site. Figure 7 shows the particle size distribution (PSD) of the tailings, using AS 1289.3.6.2 1995 (Standards Australia 1995a). The material can be classified as ML (sandy silt) according to the Unified Soil Classification System (USCS). The specific gravity of the tailings was 2.78, using AS 1289.3.5.1 1995 (Standards Australia 1995b). The two circles in Figure 7 are the values used to differentiate paste fill and hydraulic fill materials. They suggest paste fill should contain at least $15 \%$ passing $20 \mu \mathrm{m}$, as indicated by the filled circle. This is required in order to retain water to achieve reliable paste flow (Henderson et al. 2005). On the other hand, hydraulic fill material requires no more than $10 \%$ of particles finer than $10 \mu \mathrm{m}$ to achieve adequate permeability, as indicated by the open circle (Grice 2005). Since the PSD lies above these two points, the Lanfranchi tailings can be regarded as paste fill material according to these definitions.

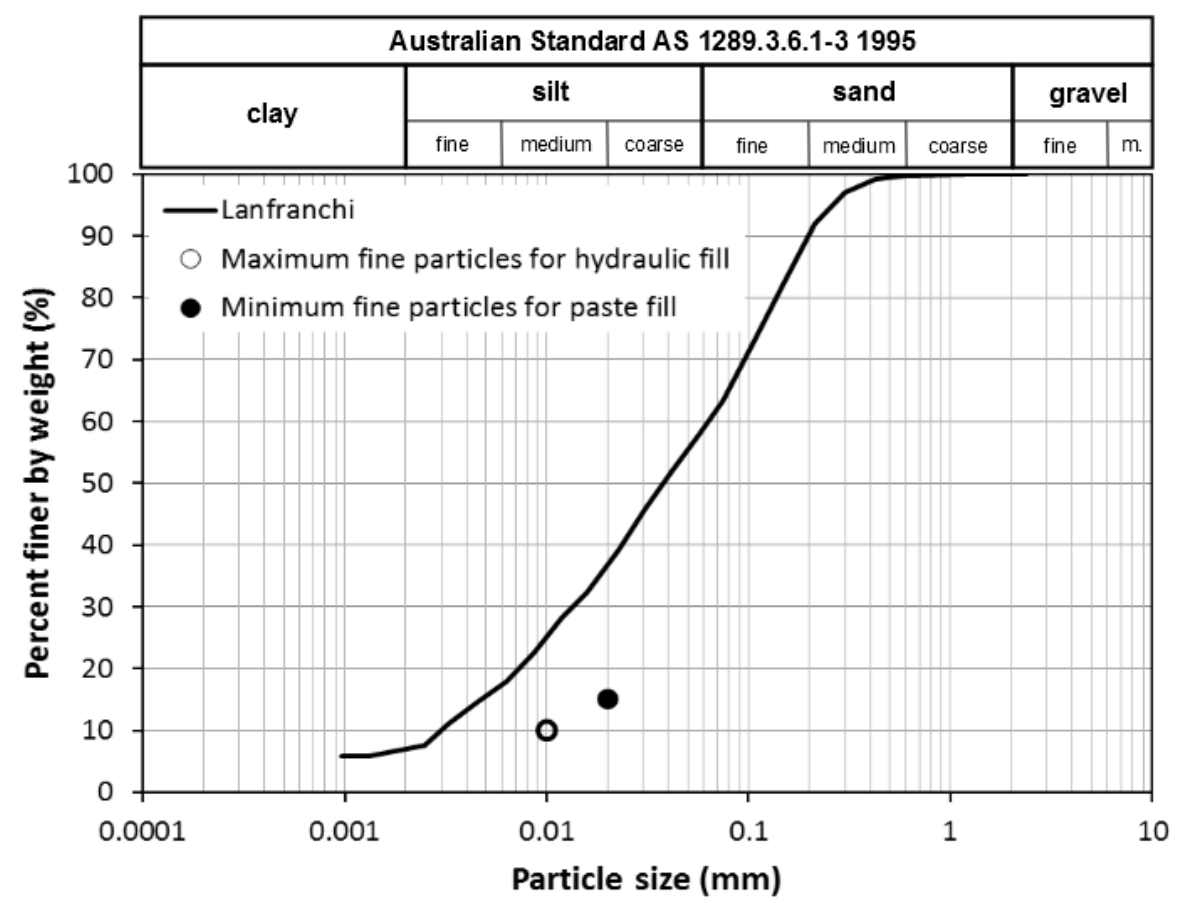

Figure 7 Particle size distributions of Lanfranchi tailings

\subsection{Process water}

The process water is hypersaline ground water with a total dissolved solids (TDS) and conductivity values of $89,500 \mathrm{ppM}$ and $127,200 \mu \mathrm{S} / \mathrm{cm}$, respectively. As a comparison, seawater has TDS and conductivity values of $33,300 \mathrm{ppM}$ and $55,350 \mu \mathrm{S} / \mathrm{cm}$, respectively. The process waters were tested using TPS WP 81 with a $k=10$ sensor. The salinity of the water may affect the cementation process (Steinour 1960).

\subsection{CPB mixture}

The CPB had $75.4 \%$ solid content, with $3.75 \%$ cement binder. The bulk density and the dry density of the CPB were 1.9 and $1.4 \mathrm{t} / \mathrm{m}^{3}$, respectively. The chemical additive MMR01, which is used to improve the pumpability, was added to the CPB at $4 \mathrm{l} / \mathrm{t}$ of cement. The average slump value of the CPB slurry was $220 \mathrm{~mm}$ and the unconfined compressive strength (UCS) of the CPB was $500 \mathrm{kPa}$ after 14 days curing time. 


\section{$4 \quad$ Backfilling}

The CPB was transported from the paste plant to the stope via reticulation pipes by gravity alone. The backfilling was conducted in six stages, with an average filling rate of $120 \mathrm{~m}^{3} / \mathrm{h}$. Considering the geometry of the stope, the average rate of rise was $0.7 \mathrm{~m} / \mathrm{h}$. A plot of the fill height against time, measured in days from the commencement of filling, is given in Figure 8. Note that the filling schedule was determined by operational conditions. The flat parts of the fill progress curve indicate rest periods. The planned rest periods took place between stages. Few unplanned rest periods also took place due to technical problems during the filling for short period of time (one hour or less). The sensors were installed at the elevation of the middle drive and the measurements only commenced once the fill height exceeded $18.7 \mathrm{~m}$. Figure 9 illustrates the approximate level after each stage in the stope. It shows that stage 1 , stage 2 (partly) and stage 3 were used as 'plug fills' for the lower barricade and the middle barricade, respectively.

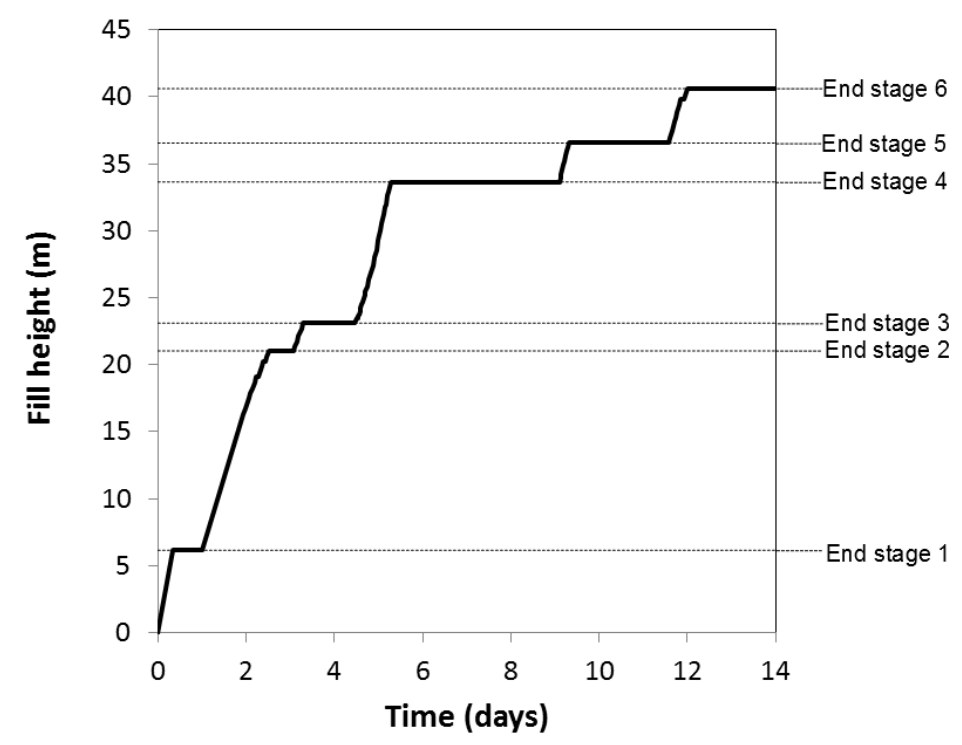

Figure 8 Fill height against time

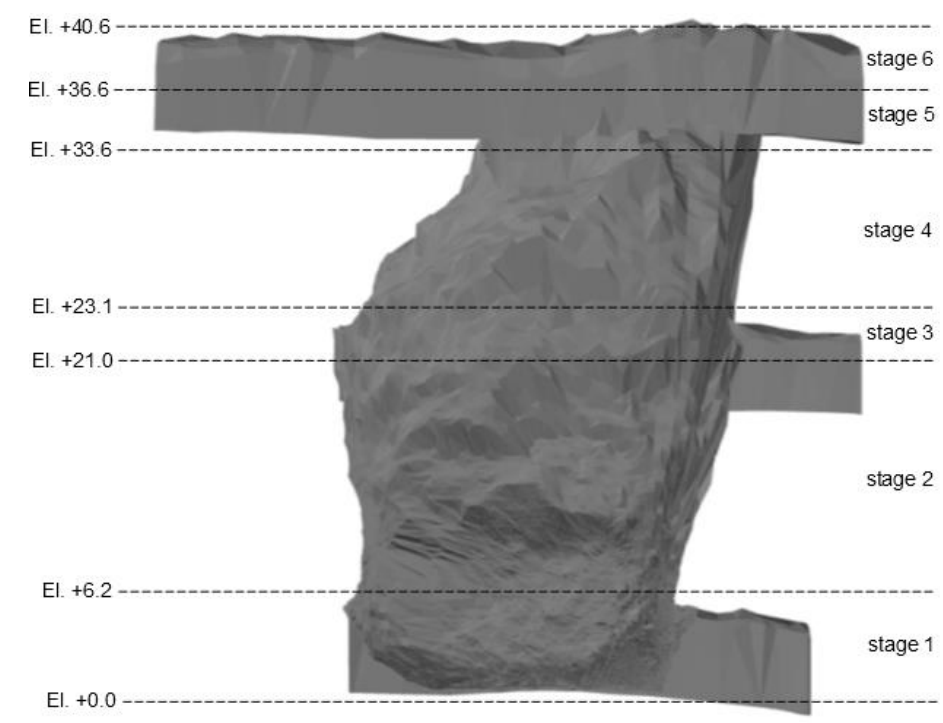

Figure 9 Filling stages

\section{$5 \quad$ Results and discussions}

Sensor recordings are plotted as stress or pressure against elapsed time. Stage 1 filling commenced at 11:35 am on 4 August 2013. This time is used as a reference (time $=0$ day). The measurements were 
acquired continuously for 14 days, before blasting of an adjacent stope required the data logger to be removed.

In the figures, the geostatic stress $(\mathrm{kPa})$ is superimposed. The geostatic stress may be used as reference to compare sensor measurements. It is estimated as follows:

$$
\text { Geostatic }=\gamma\left(h_{f}-h_{s}\right)
$$

Where:

$$
\begin{aligned}
& \gamma=\text { unit weight of the CPB is } 18.64 \mathrm{kN} / \mathrm{m}^{3} . \\
& h_{f}=\text { the elevation of fill }(\mathrm{m}) . \\
& h_{s}=\text { the elevation of sensor }(\mathrm{m}) .
\end{aligned}
$$

Figure 10 shows the horizontal stress, vertical stress and pore water pressure measurements at location 1 , as well as the geostatic vertical stress. The total stress (horizontal and vertical) and pore water pressure increased in response to stage 2 filling, until the filling stopped at $t=2.53$ days for a period of 13 hours (shown by the flat line of the geostatic stress). Note, two short rest periods of about one hour each also took place at $t=2.24$ and $t=2.39$ prior to the 13 hour rest period. These two rest periods did not significantly reduce either the total stress or the pore water pressure. At the beginning of the 13 hour rest period, horizontal and vertical stresses measured 41.2 and $41.3 \mathrm{kPa}$, respectively. These values are close to the estimated geostatic stress of $44 \mathrm{kPa}$. The pore water pressure is slightly lower than both total stresses, i.e. $36 \mathrm{kPa}$. This indicates that initial filling is almost undrained. During the 13 hour rest period, pore water pressures reduced due to consolidation and hydration. The consolidation settled the fill mass, which might potentially generate stress arching onto the stope walls. As the stage 3 filling commenced (at 3.07 days), the total stresses and pore water pressure increased until the start of the next rest period at 3.29 days. However, the stresses and pore water pressure values are significantly lower than the estimated geostatic stress. This is attributed to some of the total stress being distributed onto the surrounding rock mass.

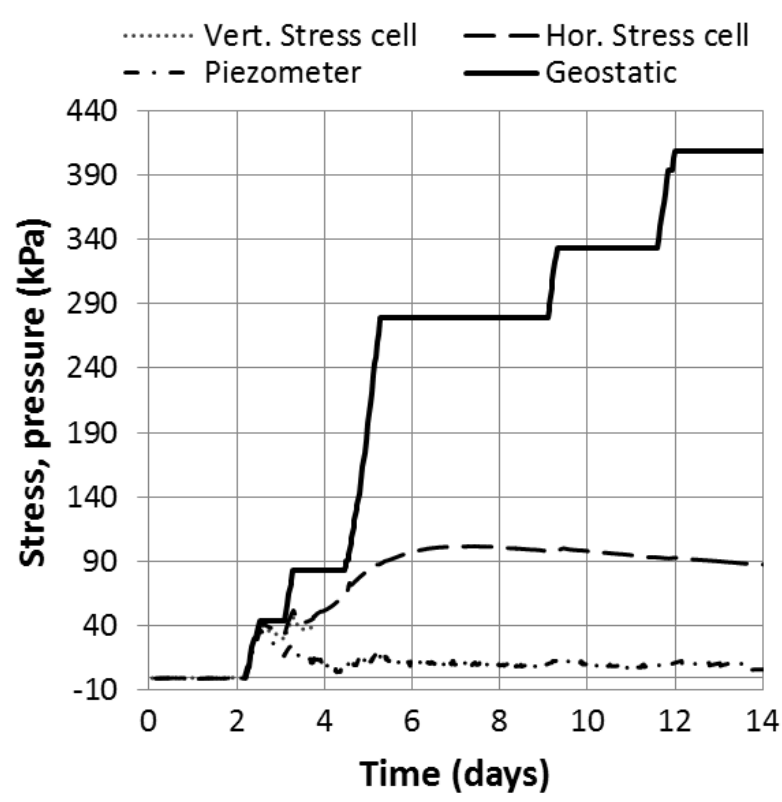

(a)

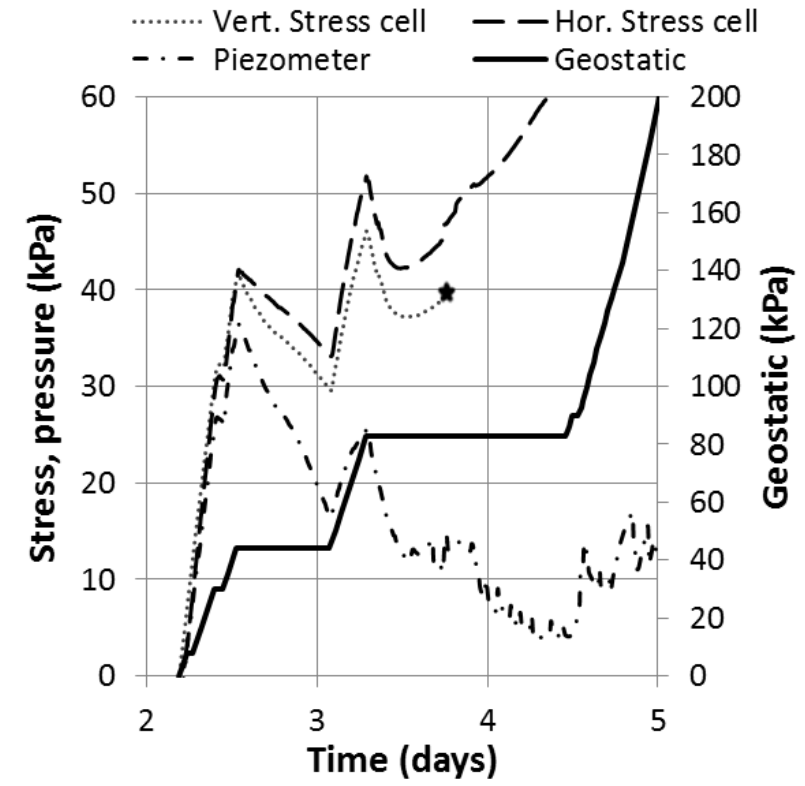

(b)

Figure 10 Measurements at location 1; (a) full chart; (b) enlarged. Note that ${ }^{\star}$ indicates the time when the sensor malfunctioned

Immediately after the start of the second rest period, the horizontal stress, vertical stress and the pore water pressure decreased, indicating consolidation was progressing. However, 0.2 days into this rest 
period, both total stresses began increasing again even though no additional fill was added. There was no corresponding increase in the pore water pressure. It is unclear why this occurs. Other in-stope surveys (Thompson et al. 2012; Hasan et al. 2013) observed the same phenomenon. After 3.7 days, the vertical stress cell displayed erroneous readings, indicating likely physical damage of the sensor (shown as a 'star' symbol in Figure 10b). The horizontal stress reached a maximum value of $101.5 \mathrm{kPa}$, after the completion of stage 4, and then slowly diminished to $85 \mathrm{kPa}$ after 14 days. There was insignificant increase in total stress due to later filling. Unlike the two total stresses, the pore water pressure continued to drop and stabilised at around 5-10 $\mathrm{kPa}$.

Figure 11 shows the sensor recordings at location 2 . At the beginning of the initial 13 hours rest period, the total vertical and horizontal stresses measured 43.7 and $39.9 \mathrm{kPa}$, respectively. The two total stresses became almost equal at the end of the 13 hour rest period. The vertical and horizontal stresses increased to about 120 and $75 \mathrm{kPa}$ after 14 days, respectively. An insignificant total stresses increase (jump) is shown due to the later filling stage. A similar response at location 1 was noted whereby an increase in total stress was measured during the second rest period. The pore water pressure stabilised between 10-13 $\mathrm{kPa}$. A suction of $-3.8 \mathrm{kPa}$ was recorded for a short period of time at around 4.5 days. Suction was not measured by the piezometer at location 1 .

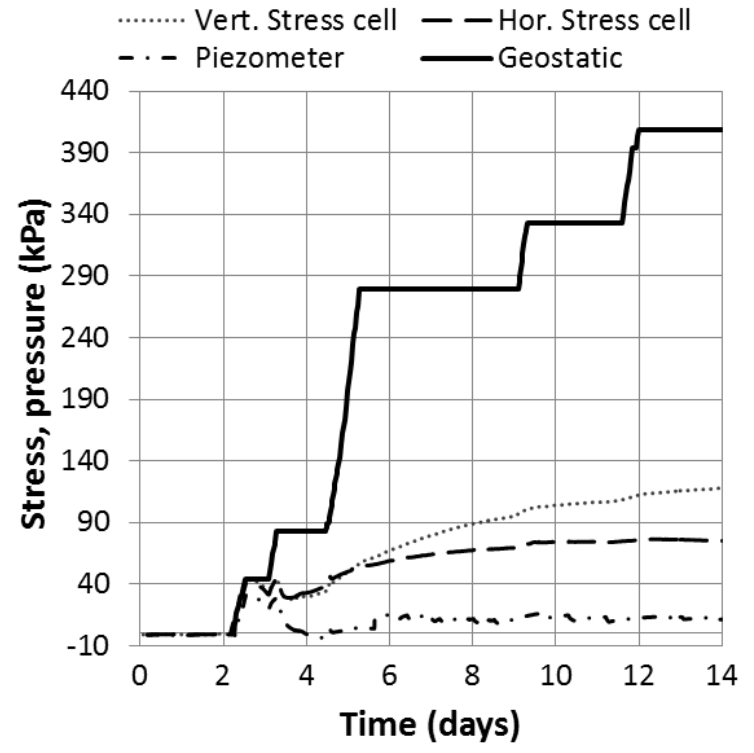

(a)

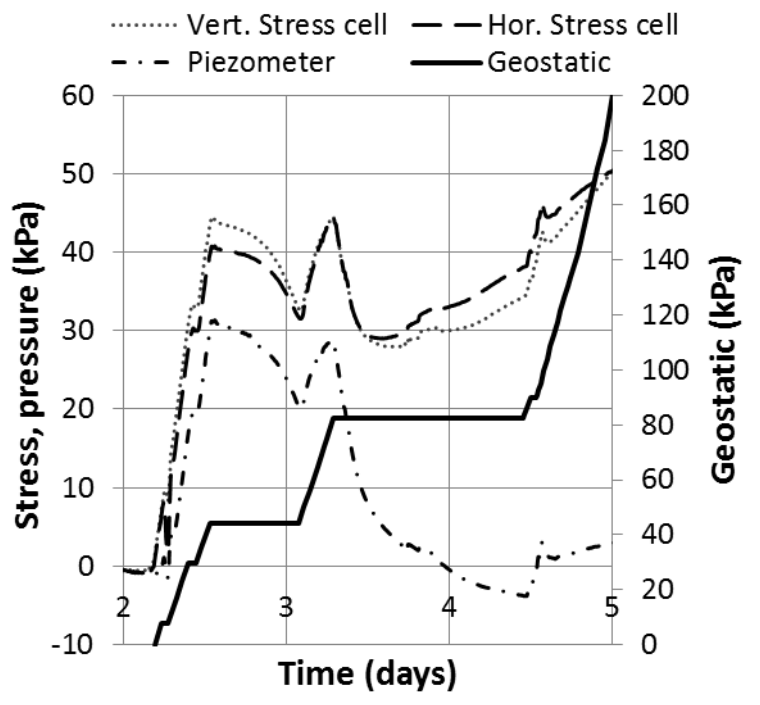

(b)

Figure 11 Measurements at location 2; (a) full chart; (b) enlarged

The sensor recordings at location 3 are shown in Figure 12. Before the 13 hours rest period, the responses were similar to those at locations 1 and 2, except that the overall magnitudes of measurements are lower than the other two locations. The total horizontal and vertical stress measured 37 and $34.5 \mathrm{kPa}$, respectively. However, after the initial rest period, the vertical stress showed a greater increase than the horizontal. After 3.7 days the three sensors showed erroneous readings, probably due to some form of physical damage to the sensors.

In general, the results presented in this paper show similar correlations between pore pressure measurements and total stress measurements. During initial filling there is a direct correlation between both the pore pressures and total stresses and the geostatic stress. When filling stops and a rest period occurs, the total stresses and pore pressures decrease. This response is consistent with what would be expected, where an increase in stress and pore pressure is due to an increase in overburden. A subsequent drop in these values (when filling stops) is due to pore pressure dissipation, thus consolidation occurs. 
However, an unexpected response is evident thereafter, and has previously been noted by Thompson et al. (2012) and Hasan et al. (2013). Considering Figure 10 (location 1), after about 2.5 days filling stops and a rest period begins. As discussed above, the pore pressure and the total stresses respond by decreasing in value. When filling recommences at around 3.1 days, the sensors all show a corresponding increase in value until the end of this filling stage at around 3.3 days, after which the values again begin to drop. However, after approximately 3.5 days, during the rest period, both the horizontal and vertical total stresses increase. This occurs despite no change in the amount of fill placed. Both total stresses continue to climb, and when filling re-starts at about 4.5 days, the horizontal total stress had reached about $63 \mathrm{kPa}$ (compared with about $82 \mathrm{kPa}$ geostatic stress). Similar behaviour was evident at location 2, although to a lesser extent. It also occurred at location 3 , but unfortunately this response could only be tracked until about 3.5 days, due to loss of recordings after that time.

This anomalous behaviour has been observed a number of times and should not be dismissed as instrument malfunction, remembering that it has also been reported by other workers (Thompson et al. 2012; Hasan et al. 2013). Importantly, it is not recorded by the piezometers. Thus, if only piezometers were used, the rise in horizontal stress (particularly at the barricade location) would not be detected. Clearly, this is undesirable and indicates that, at least until the reason for the unexplained rise in total stress is understood, the continued use of total stress cells is advisable.

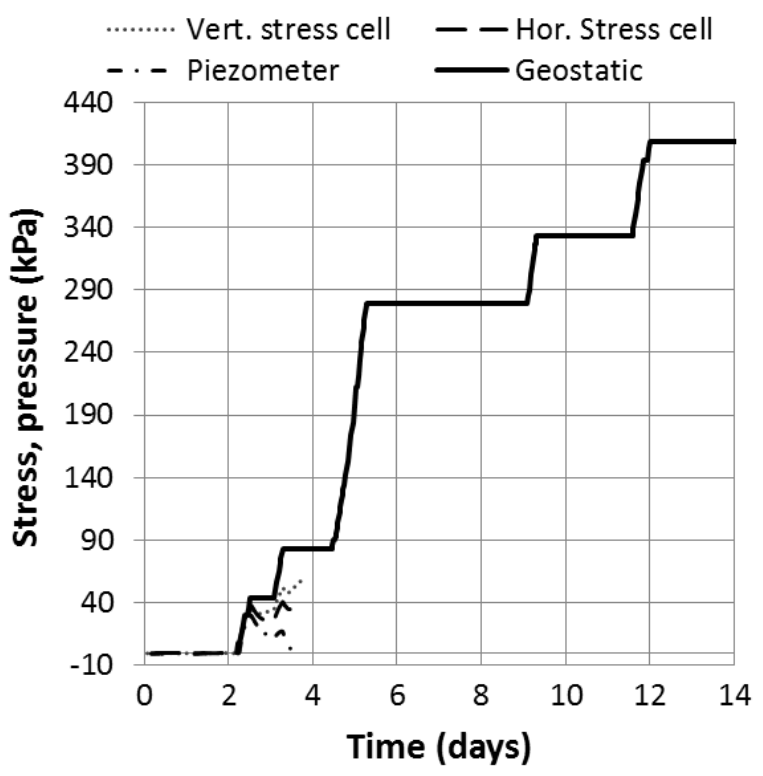

(a)

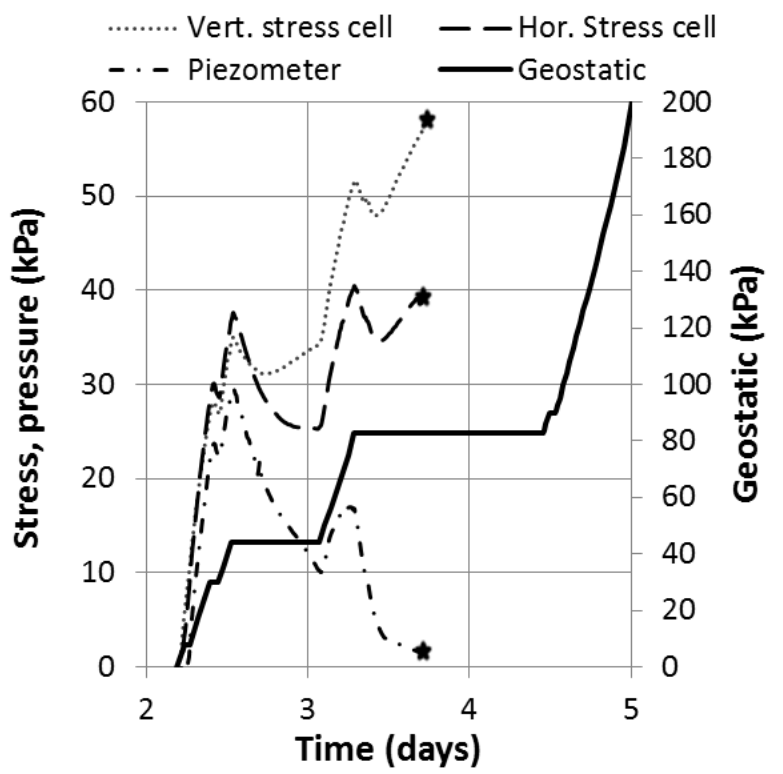

(b)

\section{Figure 12 Measurements at location 3; (a) full chart; (b) enlarged. Note that ${ }^{\star}$ indicates the time} when the sensors malfunctioned

\section{Conclusions}

Results from in-stope monitoring of cemented paste backfilling at the Lanfranchi mine site have been presented. As the fill height passes the instrument locations, the total stress and pore pressures are similar, indicating material deposited in an undrained state and the effective stresses are very low. During the initial rest period, pore pressures and total stresses drop. The reduction in pore pressure exceeds that of the total stress and material develops effective stress and frictional strength. However, a rise in total stress during the subsequent rest periods was evident at all three locations. The mechanism causing this remains unclear. Unfortunately the time over which data was acquired was limited due to unavoidable interruptions from production blasting. Nevertheless, the value of in-stope instrumentation has been demonstrated; for example, measured horizontal stresses in the drawpoint provide valuable information for calibrating barricade design methods. 


\section{Acknowledgement}

The authors acknowledge funding provided by an ARC Linkage Grant (LP100200173) in collaboration with Panoramic Resources Ltd. The authors also thank Nils Spanoghe, Simon Cheesman, Jake Campbell, Adrian Leiblich, Michael Timbs, Tim Mason and other Lanfranchi site staffs for their cooperation and assistance during the field testing.

\section{References}

Belem, T, Harvey, A, Simon, R \& Aubertin, M 2004, 'Measurement and prediction of internal stresses in an underground opening during its filling with cemented fill', Proceedings of the Fifth International Symposium on Ground Support in Mining and Underground Construction, in E Villaescusa \& Y Potvin (eds), Balkema, Rotterdam, pp. 619-30.

Fourie, AB, Fahey, M \& Helinski, MB 2007, 'Using effective stress theory to characterize the behaviour of backfill', Proceedings of the 9th International Symposium on Mining with Backfill, in FP Hassani \& JF Archibald (eds), Canadian Institute of Mining, Metallurgy and Petroleum, Westmount, on CD-ROM.

Grabinsky, M, Bawden, WF \& Thompson, BD 2007, 'In situ monitoring of cemented paste backfill in an Alimak stope', Proceedings of the 60th Canadian Geotechnical Conference and 8th Joint IAH-CNC and CGS Groundwater Specialty Conference, Canadian Geotechnical Society and International Association of Hydrogeologists: Canadian National Chapter, Ottawa, pp. 2237-44.

Grice, AG 2005, 'Introduction to Hydraulic Fill', in Handbook on Mine Fill, in Y Potvin, EG Thomas \& AB Fourie (eds), Australian Centre for Geomechanics, Perth, Western Australia, pp. 67-79.

Hasan, A, Suazo, G \& Fourie, A.B. 2013, 'Full scale experiments on the effectiveness of a drainage system for cemented paste backfill', Proceedings of the 16th International Seminar on Paste and Thickened Tailings, eds RJ Jewell, AB Fourie, J Caldwell \& J Pimenta, Australian Centre for Geomechanics, Perth, pp. 379-92.

Hassani, F, Fotoohi, K, \& Doucet, C 1998, 'Instrumentation and backfill performance in a narrow vein gold mine', International Journal of Rock Mechanics and Mining Sciences, vol. 35, no. 4/5, paper no. 106.

Helinski, M, Fahey, M \& Fourie, AB, 2011, 'Behavior of Cemented Paste Backfill in Two Mine Stopes', Journal of Geotechnical and Geoenvironmental Engineering, vol. 137, no. 2, pp. 171-182.

Henderson, A, Revell, MB, Landriault, D \& Coxon, J 2005, 'Paste Fill', in Handbook on Mine Fill, in Y Potvin, EG Thomas \& AB Fourie (eds), Australian Centre for Geomechanics, Perth, Western Australia, pp. 83-97.

Oullet, J \& Hassani, FP 2005, 'Study of cemented pastefill and rock mass interaction and behavior in backfilled stopes', Proceedings of the 40th U.S. Symposium on Rock Mechanics (USRMS): Rock Mechanics for Energy, Mineral and Infrastructure Development in the Northern Regions, in G Chen, S Huang, W Zhou \& J Tinucci (eds), American Rock Mechanics Association, Alexandria.

Panoramic Resources Ltd 2011, Lanfranchi Operations Factsheet, Panoramic Resources Ltd, Perth, viewed 15 November 2013, http://www.panoramicresources.com/display/index/lanfranchi.

Standards Australia 1995a, AS 1289.3.6.2 - 1995: Soil classification tests - Determination of the particle size distribution of a soil Analysis by sieving in combination with hydrometer analysis (subsidiary method), Standards Australia, Sydney.

Standards Australia 1995b, AS 1289.3.5.1 - 1995: Soil classification tests - Determination of the soil particle density of a soil Standard method, Standards Australia, Sydney.

Steinour, HH 1960, 'Concrete mix water - How impure can it be?', Portland Cement Association Journal, vol. 2, no. 3, pp. 32-50.

Sveinson, S. 1999, 'Characterisation of Tailings for Paste Backfill System Design', master thesis, The University of British Columbia.

Thompson, B, Bawden, W \& Grabinsky, M 2012, 'In situ measurements of cemented paste backfill at the Cayeli Mine', Canadian Geotechnical Journal, vol. 49, pp. 755-72.

Thompson, B, Grabinsky, M \& Bawden, W 2009, 'In-situ measurements of cemented paste backfill in long-hole stopes', Proceedings of the 3rd Canada-US Rock Mechanics Symposium \& 20th Canadian Rock Mechanics Symposium, in M Diederichs \& G Grasselli (eds), University of Toronto Press, Toronto, on CD-ROM.

Yumlu, M 2001, 'Backfill Practices at Çayeli Mine', Proceedings of the 17th International Mining Congress and Exhibition of Turkey, in E Ünal, B Ünver \& E Tercan (eds), The Chamber of Mining Engineers of Turkey, Ankara, pp. 333-9. 